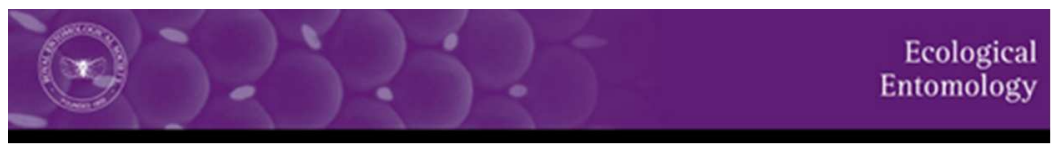

\title{
Life in harsh environments: carabid and spider trait types and functional diversity on a debris-covered glacier and along its foreland
}

\begin{tabular}{|r|l|}
\hline Journal: & Ecological Entomology \\
\hline Manuscript ID & $17-0106-$ EEN.R1 \\
\hline Manuscript Type: & Original Article \\
\hline Date Submitted by the Author: & 25 -May-2017 \\
\hline Complete List of Authors: & $\begin{array}{l}\text { Gobbi, Mauro; MUSE-Science Museum, } \\
\text { Ballarin, Francesco; University of the Chinese Academy of Sciences } \\
\text { Brambilla, Mattia; MUSE-Science Museum } \\
\text { Compostella, Chiara; University of Milan, } \\
\text { Isaia, Marco; Università di Torino, Diparitmento di Biologia Animale e } \\
\text { dell'Uomo } \\
\text { Losapio, Gianalberto } \\
\text { Maffioletti, Chiara; MUSE-Science Museum } \\
\text { Seppi, Roberto; University of Pavia, } \\
\text { Tampucci, Duccio; Universita degli Studi di Milano } \\
\text { Caccianiga, Marco; University of Milan, }\end{array}$ \\
\hline Keywords: & $\begin{array}{l}\text { Araneae, Carabidae, colonisation, dispersal power, hunting strategies, } \\
\text { turnover }\end{array}$ \\
\hline
\end{tabular}


Life in harsh environments: carabid and spider trait types and functional diversity on a debris-covered glacier and along its foreland

Mauro Gobbi*, Francesco Ballarin, Mattia Brambilla, Chiara Compostella, Marco Isaia, Gianalberto Losapio, Chiara Maffioletti, Roberto Seppi, Duccio Tampucci and Marco Caccianiga

Life-history trait types and functional diversity in carabid and spider assemblages living on the glaciers surface, or colonising recently deglaciated terrains, are still few known.

We found that dispersal abilities and hunting strategies are two key factors affecting the species survival in harsh landforms quickly changing to global warming.

Our study sheds new light on how functional approach improves our knowledge on the adaptive strategies of ground-dwelling arthropods in colonising glaciers surface and recently deglaciated terrains. 
1 Life in harsh environments: carabid and spider trait types and functional

2 diversity on a debris-covered glacier and along its foreland

3

4

5

6

7

8

Mauro Gobbi ${ }^{*}$, Francesco Ballarin ${ }^{2}$, Mattia Brambilla $^{3,4}$, Chiara Compostella ${ }^{5}$, Marco Isaia ${ }^{6}$, Gianalberto Losapio ${ }^{7}$, Chiara Maffioletti ${ }^{1}$, Roberto Seppi ${ }^{8}$, Duccio Tampucci ${ }^{9}$, and Marco

Caccianiga $^{9}$

${ }^{1}$ Section of Invertebrate Zoology and Hydrobiology, MUSE - Museo delle Scienze, Corso del Lavoro e della Scienza 3, I-38123, Trento (Italy)

${ }^{2}$ Institute of Zoology, Chinese Academy of Sciences, Beijing 100101 (China)

${ }^{3}$ Section of Vertebrate Zoology, MUSE - Museo delle Scienze, Corso del Lavoro e della Scienza 3, I-38123, Trento (Italy), ${ }^{4}$ Settore Biodiversità e Aree Protette, Fondazione Lombardia per

l'Ambiente, Largo 10 luglio 1976, 1, I-20822 Seveso (MB), Italy

${ }^{5}$ Department of Earth Sciences “Ardito Desio”, Università degli Studi di Milano, Via Celoria 26, I20133 Milano (Italy)

${ }^{6}$ Department of Life Sciences and Systems Biology, University of Torino, Via Accademia Albertina 13, I-10123 Torino (Italy)

${ }^{7}$ Departement of Evolutionary Biology and Environmental Studies, University of Zurich, Winterthurerstrasse 190, CH-8057 Zurich (Switzerland)

${ }^{8}$ Department of Earth and Environmental Sciences, Università degli Studi di Pavia, Via Ferrata 1, 27100 Pavia (Italy)

${ }^{9}$ Department of Biosciences, University of Milan, Via Celoria 26, I-20133 Milan, Italy

Running title: Functional traits in harsh environments 
27

$28 *$ Corresponding author:

29

30 Mauro Gobbi, PhD

31 Section of Invertebrate Zoology and Hydrobiology

32 MUSE - Museo delle Scienze, Corso del Lavoro e della Scienza 3, I-38123, Trento (Italy)

33 Email: mauro.gobbi@muse.it

34 


\section{Abstract.}

1. Patterns of species richness and species assemblage composition of ground-dwelling arthropods in primary successions along glacier forelands are traditionally described using a taxonomic approach. On the other hand, the functional trait approach could ensure a better characterization of their colonisation strategies on these kind of habitats.

2. We applied the functional trait approach to investigate patterns of functional diversity and life-history traits of ground beetles and spiders on an alpine debris-covered glacier and along its forefield in order to describe their colonization strategies.

3. We sampled ground beetles and spiders in different successional stages, representing five stages of deglaciation.

4. Our results showed that the studied glacier hosts ground beetle and spider assemblages mainly characterized by the following traits: walking colonisers, ground hunters and small sized species. These traits are typical of species living in cold, wet and gravelly habitats. The diversity of functional traits in spiders increased along the succession, and both in carabids and spiders, life-history traits follow the "addition and persistence model". Accordingly, there is no turnover but there is an addition of new traits and a variation in their proportion within each species assemblage along the succession. The distribution of ground beetles and spiders along the glacier foreland and on the glacier seems to be driven by dispersal ability and foraging strategy.

5. The proposed functional approach improves our knowledge on the adaptive strategies of ground-dwelling arthropods in colonising glaciers surface and recently deglaciated terrains, which represent landforms quickly changing due to global warming.

Key-words: Araneae, Carabidae, colonisation, dispersal power, hunting strategies, turnover. 


\section{Introduction}

Two of the main visible effects of climate warming on alpine areas are glacier retreat and increasing supraglacial debris on glacier surfaces (e.g. Citterio et al., 2007; Paul et al., 2007).

Several studies describe the structural changes (species richness trends and species turnover/persistence) in ground-dwelling arthropod assemblages along the primary succession on recently deglaciated areas (i.e. glacier forelands) (see Hagvar, 2012). Spatial distribution of grounddwelling arthropods is mainly determined by site age (time since deglaciation), with its related local fine-scale environment conditions, such as soil grain size, vegetation cover and/or soil organic matter (see. Kaufmann, 2001; Brambilla \& Gobbi, 2014; Tampucci et al., 2015). More recently, attention has shifted from the glacier forelands to the surface of debris-covered glaciers, because of the emerging interest of debris-covered glaciers as suitable habitats for micro-, meso- and macrofauna and plant life (Caccianiga et al., 2011; Gobbi et al., 2011; Azzoni et al., 2015). Debriscovered glaciers are formed by frequent slipping and casting of deposits creating large quantities of stony material which covers the glacier surface, in particular on the ablation area (Citterio et al., 2007), and they significantly increased during the last decade. Arthropod distribution on debriscovered glaciers is mainly determined by rock grain size, debris thickness, glacier movements/instability, and microclimate conditions (Gobbi et al., 2011).

Traditionally, a taxonomic approach was used to describe ground-dwelling arthropod assemblages along primary successions (e.g. Kaufmann, 2001, Gobbi et al., 2006, Vater, 2012), on the other hand the functional trait approach has been rarely applied even if it can be useful to understand ecosystem complexity and dynamics (Diaz \& Cabido, 2001; Losapio et al., 2015; Moretti et al. 2017). A possible reason might be the lack of knowledge about traits of many taxa and whether these traits are related to environmental changes.

Ground beetles (Coleoptera: Carabidae) and spiders (Arachnida: Araneae) can be considered among the most important meso- and macro-fauna living on recently deglaciated terrains in terms of species richness and abundance (Hagvar, 2012). Carabid beetle and spider life-history traits along 
86

87

environmental gradients (see Schirmel et al., 2012; Pizzolotto et al., 2016) are quite well known in terms of response traits (sensu Díaz et al., (2013), i.e. traits that impact on individuals' capacity to colonise and persist in a habitat). On the other hand, there are no studies involving both spider and ground beetle life-history traits that describe, by means of a functional approach, the grounddwelling arthropod functional diversity and the turnover of life-history traits along a primary succession on glacier forelands and on the glacier surfaces. The functional trait approach would ensure a better characterization of the arthropod colonisation strategies on the glaciers and on terrain left free by retreating glaciers.

The study area selected to shade light on this topic is one of the few known cases in the Italian Alps in which it is possible to investigate, at the same time, the species assemblage colonisation and the survival strategies on a debris-covered glacier surface and along more than one-hundred and sixty year glacier foreland chronosequence. Therefore, firstly, we described the carabid and spider species assemblages and life-history traits on the debris covered glacier, then we analysed the species richness, life-history trait and functional diversity patterns along the chronosequence of Holocene glacier retreat. Specifically we (i) tested whether species richness as well as functional diversity increase with time since deglaciation and (ii) hypothesized that time since deglaciation triggers the turnover of life-history traits. 


\section{Material and Methods}

\section{Study area}

The study was carried out on the glacier foreland of Vedretta d'Amola glacier (Adamello-Presanella Group, Central-Eastern Italian Alps, $\left.46^{\circ} 13^{\prime} 12^{\prime \prime}-10^{\circ} 41^{\prime} 02^{\prime \prime}\right)$ (Fig. 1), and on the glacier surface. Vedretta d'Amola glacier is a debris-covered glacier of c. 82.1 hectares (area recorded by one of the authors, RS, in summer 2012), covered approximately for $70 \%$ by stony debris with variable depth, from a few centimeters to about one meter. The glacier tongue is located above the treelin $\square$ The glacier foreland is c. $1.23-\mathrm{km}$ long, covers an altitudinal range of c. 150 meters, and is characterized by a large moraine system dating back to the Little Ice Age (LIA, c. AD 1850). Field observations and various sources including maps, reports, aerial photographs, iconography, and records of length change collected over the last 100 years allowed us to reconstruct the glacier tongue position during the LIA, in 1925, in 1994, and in 2003 (Fig. 1).

The snow-free period usually lasts from late June to late September. Annual mean ground temperature on the glacier foreland, recorded during the period 5 August $2011-5$ August 2012, was $1.7^{\circ} \mathrm{C}$, while $\bigcirc$ an relative air humidity was $96 \%$ (datalogger located at about $15 \mathrm{~cm}$ depth in the stony debris at plot 10, see Fig. 1 and Figure S1 - Supporting Information). The mean annual temperature, recorded during the period 15 July 2011 - 15 July 2012, on the supraglacial debris was $0.5^{\circ} \mathrm{C}$ (datalogger located at $10 \mathrm{~cm}$ depth in the supraglacial debris at plot 2, see Fig. 1 and Figure S1 - Supporting Information).

On the supraglacial debris (mean elevation: $2642 \mathrm{~m}$ asl) the pioneer plant community (total plant cover $<10 \%$ ) is dominated by Cerastium uniflorum, $C$. pedunculatum, and Saxifraga oppositifolia. On the glacier foreland (mean elevation: $2520 \mathrm{~m}$ asl) the plant community (plant cover ranging from $5 \%$ to $70 \%$ along the foreland) is dominated by Poa alpina, P. laxa, Saxifraga bryoides, Geum reptans, and Luzula alpino-pilosa. Outside the glacier foreland (mean elevation: $2426 \mathrm{~m}$ asl), Late Glacial sites are occupied by Carex curvula-dominated communities with $>80 \%$ ground cover. 
Sampling design

132 We selected eleven sampling plots located along a linear transect starting on the glacier surface and ending on Late Glacial substrata outside the LIA moraines (Fig.1). We assigned to each plot a class base of the following two criteria: (i) areas not subjected to physical disturbance (e.g. rockslides, river flooding), (ii) detection probability of the considered species (e.g. on the glacier surface class 0 - we located four plots due to the low species detection probability (see Tenan et al., 2016)).

Sampling method

We sampled carabid beetles and spiders using pitfall traps (Eymann et al., 2010). In each plot three traps were located about 10 m apart (Kotze et al., 2011), which led to a total of 33 pitfall traps.

Traps consisted of plastic vessels $(7 \mathrm{~cm}$ of diameter and $10 \mathrm{~cm}$ of height) baited with a mixture of wine-vinegar and salt. The traps were active over the entire snow free seasons, from early July to late September 2011-2012. Samples were taken at 25-day intervals. Plots 2, 4, 5, 8 and 10 were studied in year 2011, whereas plots 1, 3, 6, 7, 9 and 11 were studied in 2012 in order to optimize the sampling effort in this kind of harsh environments. Since temperature is one of the main factors affecting carabids life cycle, distribution, and species assemblage composition in montane habitats (Kotze et al., 2011), the choice to sample in two different sampling years could be a bias in our dataset. Thus, we compared the annual mean temperature in each of the sampling year (2011 vs 2012). We considered air temperatures data from the nearest (c. $6,5 \mathrm{~km}$ from our study site) meteorological station (Pinzolo -Italy; lat: 4609'22’'-1045’25’', elevation: $760 \mathrm{~m} \mathrm{slm}$; 
155

156

157

158

159

160

161

162

163

164

165

166

167

2012. Given that no important variation in air temperature was found, we can assume that it did not affect the carabid beetle assemblage richness and composition in the two sampling seasons.

Carabids were identified to the species level following Pesarini \& Monzini (2010, 2011), while spiders were identified to the species level following Netwing et al., (2017).

Nomenclature refers to the checklist of the European Carabid beetles Fauna (Vigna Taglianti, 2013) and to The World Spider Catalogue (WSCA, 2017). For spiders, juveniles were excluded from the analysis.

\section{Environmental variables}

We recorded abiotic (percentage of gravel, soil $\mathrm{pH}$, and soil organic matter) and biotic (plant species richness and vegetation cover) variables within a buffer of $1 \mathrm{~m}$ around each trap.

We collected a substrate sample of $1-2 \mathrm{~kg}$ at every plot for particle size distribution. Two hundred grams of substrate were sampled at each pitfall trap for organic matter content analysis (WalkleyBlack method: Walkley \& Black, 1934) and pH measurement. All the soil samples were taken at the surface. We recorded plant cover using a $50 \mathrm{~cm}$ diameter metal circle placed at the four opposite sides of the pitfall trap. We recorded vascular plants, bryophytes, and ground lichens occurring within the plot and visually estimate the overall vegetation cover and that of every species, with a resolution of $5 \%$. We calculated the mean values from the four $50 \mathrm{~cm}$ samplings to obtain a single value associated with each trap. For each plot, we recorded and averaged environmental variables around the three pitfall traps.

\section{Functional traits}

Carabids. We considered the following well-established response traits of primary succession (Gobbi et al., 2010; Schirmel et al., 2012): dispersal ability (high dispersal power = winged species; low dispersal power $=$ short-winged species); diet (ondrous, carnivorous), and mean body length (millimeters) of the pool of species in each trap. We analyzed for the first time along primary 
succession the following traits: larval hunting strategy (surface runner, surface walker, soil pore explorer) and adult hunting strategy (zoos $\Omega$ nophagous, olphactory-tactil predator, visual predator). Data about species traits were obtained on the base of specialized literature (Hůrka, 1996; Brandmayr et al., 2005; Homburg et al., 2014) (Table 1).

Spiders. We considered the following response traits: adult dispersal ability (flying dispersers = ballooners; ground dispersers = walkers); hunting strategies (ground hunters, sheet web weavers, other hunters) and mean body length (millimeters) of the pool of species in each trap. Traits were gathered on the base of Nentwig et al. (2017) and specific information on ballooning was derived, whenever possible from literature (Bell et al., 2005; Blandenier, 2009). We assigned functional groups according to Cardoso et al., (2011). In this respect, the mixed guild "other hunters" - small sheet web weavers and stalkers — includes in our case, Linyphiidae belonging to the subfamily Erigoninae (Salticidae are represented by one single species, and two individuals) (Table 1). For each trap, we calculated the proportion of each trait within the community.

\section{Data analysis}

Environmental variables. Due to the high number of environmental variables recorded in the field, we performed a preliminary correlation analysis in order to minimize multicollinearity-related problems on the estimate of the regression model parameters (Legendre \& Legendre, 2012) and to test if they are function of the time since deglaciation (class of deglaciation). Time since deglaciation, vegetation cover, plant species richness, soil gravel percentage, $\mathrm{pH}$ and organic matter resulted highly correlated (Spearman's rho $>0.9$ in all cases except one - time since deglaciation and $\mathrm{pH}$ - where it is $>0.7$; Table $\mathrm{S} 2$ - Supporting Information). Thus, on the basis of all previous information suggesting the importance of time since deglaciation, the latter was entered as the sole explanatory variable in statistical models. This choice was further motivated by the fact that time since deglaciation is the only variable that may influence the others, with a positive influence on 
207 plant species richness, percentage of vegetation cover, organic matter content and a negative

208 influence on $\mathrm{pH}$ and gravel percentage. Furthermore, we described time since deglaciation as the 209 main variable influencing carabid and spider primary succession along glacier forelands (see 210 Hagvar, 2012).

211

212

Diversity. Species richness was expressed as the number of species per trap (count data). According to Mason et al. (2013), we computed the index of functional richness (FRic) and functional dispersion (FDis) as descriptors of the functional diversity of carabid and spider assemblages along the succession. These two functional diversity indexes are indicators of community assembly processes (Mason et al., 2012). Functional richness (FRic) measures how much of the niche space is occupied by the species present. It is usually interpreted as an indicator for potentially used/unused niche space (Schleuter et al., 2010). Functional dispersion (FDis) estimates the dispersion of the species in the multidimensional trait space, calculated as the weighted mean distance of individual species in the traits space to the weighted centroid of all species, accounting for species relative abundance (Laliberté \& Legendre, 2010). In plots 1 and 2 of the class 0 no carabids were collected; thus, FDis were excluded when calculating FDis for the carabid community in these plots.

Species traits distribution. We analysed the turnover or 'persistence' of carabid and spider traits along the succession according to the descriptive analysis proposed by Vater (2012) and Vater \& Matthews $(2013,2015)$. Specifically, we analysed three community parameters for each class of deglaciation: (1) total functional traits (number of functional traits at plot level), (2) first appearances of functional traits (number of functional traits appearing for the first time along the succession, including first-and-last appearances), (3) last appearances of functional traits (number of functional traits appearing for the last time along the succession, including first-and-last appearances). 
Statistical analysis. Given that our data have a clear spatial structure, with three traps within each sampling plot, and that spatial autocorrelation is a key issue for studies investigating invertebrate ecology (and carabid and beetles in particular) along glacier forelands (Gobbi \& Brambilla, 2016), we adopted a modelling technique able to deal with spatially autocorrelated data. We worked with generalized least squares (GLS) models, which can incorporate the spatial structure into model's error and are one of the most performing methods for similar spatial analyses (Dormann et al., 2007; Beale et al., 2010). We thus used GLS models to estimate the potential effect of time since deglaciation on the selected traits/indexes, and checked for residuals distribution for all models for which the effect of time since deglaciation was not rejected; in all but one (proportion of winged species among ground beetles) of such cases, residual distribution approached a normal distribution. We assessed models' support by means of an information-theoretic approach (Burnham and Anderson, 2002), based on AICc (Akaike's information criterion corrected for small sample size): in all cases when the model including the factor time since deglaciation was more supported than the null model, we considered time since deglaciation as a meaningful predictor of a given trait/index; otherwise, we treated it as uninfluential for such a parameter. We run models using three different correlation structures (Gaussian, spherical and exponential; see e.g. Brambilla \& Ficetola, 2012) and obtained fully consistent results between the three runs.

The proportion of adult carabid hunting strategies with each class of deglaciation were not tested by the GLS since all the species except two (Amara erratica (Duftschmid 1812) and Notiophilus biguttatus (Fabricius 1779)) are olphactory-tactil predators, in the same way that adult feeding guilds were not tested since all species except one (Amara erratica) are carnivorous (see. Tab. 1). The proportion of carabid species with mophagous larvae was not tested by the GLS since all specie except one are carnivorous, thus we tested only the proportion of $\Omega$ mophagous individuals in each site. The spider hunting guild "other hunter" proportion was not tested by the GLS because belonging only to three species, and eight individuals. 
258 All statistical analyses were performed with the software R (R Development Core Team, 2016), 259 using FD R package version 1.0-12 (Laliberté et al., 2014) to compute the functional diversity 260 indices and the packages 'MuMIn', 'mass' and 'nlme' (Venables \& Ripley, 2002; Pinheiro et al., 261 2017; Bartoń, 2016) for GLS models.

262

263

264 


\section{Results}

Diversity trends

268

269

270

271

A total of 13 carabid species (732 individuals) and 13 spider species (91 individuals) were sampled (Table 1).

Carabid and spider species richness increased along the chronosequence of glacier retreat as described by the four classes of deglaciation $\left(\mathrm{R}_{\text {carabids }}^{2}=0.72 ; \mathrm{R}_{\text {spiders }}^{2}=0.57\right)$. Both for carabids and spiders the species richness value was low on the glacier and during the early successional stage (class 1), then it increased, but not linearly (Table 2, Fig. 2).

None of the two used functional diversity indexes of carabid assemblages resulted correlated to the time since deglaciation. Spider FRich gradually increased in relation to the time since deglaciation $\left(\mathrm{R}^{2}=0.71\right)$ and with a similar trend observed for the species richness (Table 2, Fig. 3). On the other hand, spider FDis did not change in relation to the time since deglaciation.

\section{Life-history traits proportion}

Among carabids, the proportion of surface walkers gradually increased along the chronosequence of glacier retreat as described by the four classes of age of deglaciation $\left(\mathrm{R}^{2}=0.78\right)$ (Table 2, Fig. 4).

Conversely, the proportion of surface runners $\left(\mathrm{R}^{2}=0.73\right)$ gradually decreased in relation to the time since deglaciation. Instead, the proportion of soil explorers did not change along the chronosequence. The proportion of high dispersal species reached the highest values in the early successional stages (Class 1), then gradually decreased along the chronosequence of glacier retreat $\left(\mathrm{R}^{2}=0.70\right)$ (Table 2, Fig. 4). The community weighted mean body length of the species in each trap did not change along the chronosequence.

Among spiders, the proportion of ballooners species reached the highest value on the glacier surface, then it decreased along the chronosequence of glacier retreat as described by the four classes of age of deglaciation $\left(\mathrm{R}^{2}=0.56\right)$ (Table 2, Fig. 3). The proportion of each hunting strategy 
291 did not change along the chronosequence. The mean body length of the species pool in each trap

292 increased along the chronosequence of glacier retreat $\left(\mathrm{R}^{2}=0.67\right)$ until the class 3 , then it slightly 293 decreased (Table 2, Fig. 3).

294

295 Life-history traits distribution

296 For carabids, the total number of functional traits increased among classes of deglaciation until the

297 Class 3, and then slightly decreased in class 4. Functional traits first appearances tended to decrease 298 with site age with the exception of Class 2. No last appearances occurred until Class 3, where a 299 single functional trait disappeared (Fig.5A).

300 For spiders, the total number of functional traits followed a concave pattern, with the lower values 301 in Class 0 and 4 and the higher values in Class 1, 2 and 3. Functional trait first appearances occurs 302 only within the first two classes of deglaciation, while the only one last appearance occurred in 303 Class 3 (Fig. 5B). 


\section{Discussion}

Species and their life-history traits on the debris-covered glacier

Debris-covered glaciers with their tongue descending below the treeline can host arthropod life on their surface (Gobbi et al., 2011). Our study demonstrated that a debris-covered glacier with its tongue located above the treeline, is also capable of hosting arthropods. Specifically, we collected three different ground-dwelling arthropod species on the glacier: the carabid beetle Nebria germari Heer 1837, the wolf spider Pardosa nigra (C.L. Koch, 1834) and the linyphiid spider Agyneta rurestris (C. L. Koch, 1836). The life-history traits of these species are the following: both $N$. germari and $P$. nigra are walking colonisers with low dispersal ability, as the former is shortwinged and the latter is not a ballooner, at least at the adult stage. Both species are ground hunters; specifically, N. germari is an olphactory-tactil predator (Brandmayr et al., 2005), while P. nigra is a

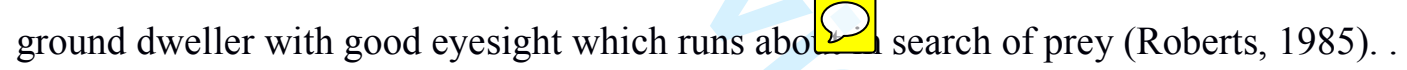

Notwithstanding these two species feed on similar preys, mainly collembolan and other insects (Raso et al., 2014) transported as aeroplankton (Hagvar, 2012), the niche competition is reduced as they have different foraging habits: the former is a nocturnal predator (Homburg et al., 2014) while the latter is mainly a diurnal predator (Raso et al., 2014). . Given the collection of juvenile instars on the glacier, it seems likely that both species complete their life cycle on the ice.

The spider Agyneta rurestris is a widespread spider in Europe and its presence on the glacier is likely to be a result of its ability to quickly colonise pioneer habitats (Meijer, 1977). For this species, however, we have no evidence of its ability to reproduce on the glacier.

\section{Diversity}

With respect to species richness values, differences among the five classes of deglaciation were found both on carabid beetles and spiders. The species richness pattern is in accordance with 
329 previous studies on invertebrate primary successions along glacier forelands (see Hagvar, 2012)

330 confirming the increasing of number of species with the time since deglaciation.

331 In contrast, the functional diversity along the chronosequence of glacier retreat revealed different

332 patterns in carabids when compared to spiders. Concerning carabids, no detectable trend was found,

333 neither for functional richness, nor for functional dispersion. According to Mason et al. (2013) this

334 result highlights that there is no change in influence of niche complementarity on either species

335 occurrences or abundances, with increasing time since deglaciation. This result indicate that in our

336 study system there are not habitat filtering processes (sensu HilleRisLambers et al., 2012), thus

337 there are no environmental factors limiting the occurrence of species without certain traits.

338 Interestingly, habitat filtering processes in carabid beetles distribution were found along glacier

339 forelands located below the treeline due to a more complex habitat and community structure

340 (Brambilla \& Gobbi, 2014; Vater \& Matthews, 2015). Probably, above the treeline the variation of

341 complexity of habitat and community structure, in relation to the time since deglaciation, is not high

342 enough to be able to filter the species/traits occurrence.

343 On the contrary, for spiders time since deglaciation affected positively the functional richness, but

344 not functional dispersion. According to Mason et al. (2013), this result highlights an increasing

345 influence of niche complementarity on species occurrences, but not abundances, with increasing of

346 time since deglaciation.

\section{Life-history trait types and distribution}

349 Traits distribution analysis revealed that on the glacier (Class 0) and during the first stage of

350 deglaciation (Class 1) the early successional carabid assemblages were characterized by species

351 with the following features: surface running larvae, mainly short-winged species, olphactory-tactil

352 predators. Surface running larvae are probably mainly linked to the gravelly soils of the early

353 successional stages, as they are effective at capturing their preys running between the stones or at

354 the edge of the stones. Accordingly to this hypothesis, species with soil exploring larvae (i.e. small 
larvae living into the soil (Brandmayr et al., 2005)) appeared in the mid- and late-successional stages, where the habitat maturity should sustain several prey species living in the soil and with a low ability to escape (e.g. earthworms, fly larvae). After 20 years since glacier retreat (Class 1) until the late successional stages (Class 3-4), all larval hunting strategies (surface walkers, surface runners, soil pore explorers, s $\mathrm{S}$ hophagous), adult diet types (carnivorous, omnivorous) and wing statuses (short-winged and winged) were represented and persisted along the glacier foreland.

Therefore, this result supports the general pattern found in other glacier forelands where the number of low dispersal species increan stable and mature environments (Gobbi et al., 2007; Gobbi et al., 2010). Most of the sampled carabid species are olphactory-tactil hunters (Brandmayr et al., 2005). This hunting strategy is considered to be the most primitive hunting strategy, performed by unspecialized nocturnal predators with small eyes (Brandmayr et al., 2005; Fountain-Jones et al., 2015). Since the olphactory-tactil hunting strategy is related to nocturnal predation (Brandmayr et $a l ., 2005)$, we can hypothesize that this strategy is particularly frequent in the species living in this kind of harsh habitats in order to partially avoid niche competition with spiders, and opiliones, which are also top-predators (Hagvar, 2012), but with diurnal habits. Visual predators appeared only in late successional stages (Classes 3-4). Visual hunting is typical of diurnal predators (e.g. Notiophilus spp.) with large eyes (Brandmayr et al., 2005; Fountain-Jones et al., 2015). Most carabids specialized in feeding on springtails occurring in late successional stages, where high vegetation cover favors high springtail abundance (Schirmel et al., 2012).

The analysis of spider trait distribution revealed that most of the hunting strategies are represented along the primary succession, but without a clear trend. The proportion of ballooners is higher on the glacier and in early successional stages, then decreased along the succession. As a consequence, the dispersal strategy (ballooners vs ground dispersers) influenced spiders' distribution. Ballooning may be initiated by both environmental and physiological factors, and in general overcrowding and food shortage can stimulate aerial dispersal (Duffey, 1998; Weyman et al., 2002), which happens during the snow free period (Coulson et al., 2003). Spider body length increased along the primary 
381 succession. Since bigger species are generally not ballooners, this trend can be explained by the 382 correlation between body size and dispersal ability. In addition, our results are consistent with 383 mechanisms invoking metabolic rate and desiccation resistance to predict an increase of body size 384 from cool and moist habitats, such as the glacier surface and early successional stages, to warmer 385 and dryer habitats, as late successional stages (Entling et al., 2010).

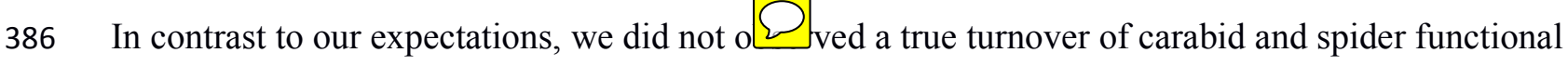
387 traits along the primary succession. Therefore, the presence of filtering process on life-history traits 388 can be excluded. Indeed, most of the traits were added and persisted, according to the "addition and 389 persistence model" (Vater, 2012; Vater \& Matthews, 2013, 2015). Our results bring to advance the 390 hypothesis that, in our study system, ground beetles and spiders occurrence on the glacier and 391 distribution along the glacier foreland seems to be driven by dispersal ability and foraging strategies 392 of each species. 


\section{Conclusions}

Our results highlighted that carabid and spider primary successions along a glacier foreland can be described not only by considering species diversity and turnover, as traditionally performed, but also via the functional diversity and traits distribution approach, as already applied to plant assemblages (e.g. Caccianiga et al., 2006; Erschbamer \& Mayer, 2012). However, unlike plant assemblages, in our study system carabid and spider species assemblages cannot be discriminated from their life-history trait types, as the traits are not mutually exclusive, but they mainly follow the "addition and persistence model" and not the "replacement change model" (Vater \& Matthews, 2012). On the other hand, the proportion of most of the considered life-history traits within each species assemblage clearly changes in relation to the successional gradient; the species assemblages can thus be discriminated on the base of the proportion of each trait. The use of life-history traits proved a useful tool to describe in more detail, the ecological and behavioral features of the grounddwelling arthropods involved in a primary succession triggered by glacier retreat.

To our knowledge, this is the first study to measure different components of functional diversity of ground-dwelling arthropods in response to glacier retreat and, in general, in harsh high-altitude environments. Using the trait-based approach and including functional diversity components, we contribute to the description of the adaptive strategies adopted by carabids and spiders colonising glaciers surfaces and recently deglaciated terrains, landforms which are rapidly changing in response to the current global warming.

\section{Acknowledgments}

We thank the Adamello-Brenta Natural Park for issuing the research permit. We are thankful to Silvia Bussolati for her fieldwork assistance. The research project was co-financed by Autonomous Province of Trento (Italy). GL was supported by the Swiss National Science Foundation 
420 (PZ00P3_148261). A. E. Vater provided English revision and useful suggestions. The Associate

421 Editor and the three referees provided very helpful comments on a first draft of the manuscript.

422

423 Contribution of authors

424 Mauro Gobbi designed the experiment, coordinated the research project, wrote the manuscript,

425 participated to the field work, and supervised carabids identification. Francesco Ballarin identified

426 the spiders. Mattia Brambilla performed the statistical analysis in R. Chiara Compostella helped in

427 the fieldwork and performed the soil analysis. Marco Isaia gave a substantial contribution to the

428 writings, especially in the discussion of spiders. Gianalberto Losapio performed the functional

429 diversity analysis adding important insights about the functional diversity trends. Chiara Maffioletti

430 helped on the field work, sorted the arthropods and identified the carabids. Roberto Seppi

431 reconstructed the chronosequence of glacier retreat and gave important information about the

432 glacier features. Duccio Tampucci performed the analysis of species turnover and contributed in

433 writing the paper. Marco Caccianiga helped in the experiment design, participated to the field work,

434 identified the plant species and supervised the final version of the manuscript. 
437

438

439

440

441

442

443

444

445

446

447

448

449

450

451

452

453

454

455

456

457

458

459

460

461

462

\section{References}

Azzoni, R.S., Franzetti, A., Fontaneto, D., Zullini, A. \& Ambrosini, R. (2015) Nematodes and rotifers on two Alpine debris-covered glaciers. Italian Journal of Zoology, 82, 616-623.

Bartoń, K. (2016) Package 'MuMIn'. R package version 1.15.6. R package https://CRAN.Rproject.org/package $=$ MuMIn

Beale, C.M., Lennon, J.J., Yearsley, J.M., Brewer, M.J. \& Elston, D. A. (2010) Regression analysis of spatial data. Ecology Letters, 13, 246-264.

Bell, J.R., Bohan, D.A., Shaw, E.M. \& Weyman, G.S. (2005) Ballooning dispersal using silk: world fauna, phylogenies, genetics and models. Bulletin of Entomological Research, 95, 69-114.

Blandenier, G. (2009) Ballooning of spiders (Araneae) in Switzerland: general results from an eleven-year survey. Arachnology, 14, 308-316.

Brambilla, M. \& Ficetola, G.F. (2012) Species distribution models as a tool to estimate reproductive parameters: a case study with a passerine bird species. Journal of Animal Ecology, 81, 781-787.

Brambilla, M. \& Gobbi, M. (2014) A century of chasing the ice: delayed colonisation of ice-free sites by ground beetles along glacier forelands in the Alps. Ecography, 37, 33-42.

Brandmayr, P., Zetto Brandmayr, T. \& Pizzolotto, R. (2005) I Coleotteri Carabidi per la valutazione ambientale e la conservazione delle biodiversità. Manuale operativo, Vol. 34. Roma: Agenzia per la protezione dell'ambiente e per i servizi tecnici, IGER. 
Caccianiga, M., Luzzaro A., Pierce S., Cerabolini B. \& Ceriani R.M. (2006) The functional basis of

a primary succession resolved by CSR classification. Oikos, 112, 10-20.

466

467

Caccianiga, M., Andreis C., Diolaiuti G., D’Agata C., Mihalcea C. \& Smiraglia C. (2011) Alpine

468

debris-covered glacier as a habitat for plant life. The Holocene, 21, 85 1011-1020.

469

Cardoso, P., Pekár, S., Jocqué, R. \& Coddington, J.A. (2011) Global patterns of guild composition and functional diversity of spiders. PLOS ONE, 6, e21710. doi:10.1371/journal.pone.0021710

472

473

Citterio, M., Diolaiuti, G., Smiraglia, C., D’Agata, C., Carnielli, T., et al., (2007) The fluctuations

474

of Italian Glaciers during the last century: A contribution to knowledge about Alpine glacier

475 changes. Geografiska Annaler, Series A. Physical Geography, 89, 167-184.

476

477

Coulson, S.J., Hodkinson, I.D. \& Webb, N.R. (2003) Aerial dispersal of invertebrates over a high-

478

479

480

481

482

483

484

485

486

487

Arctic glacier foreland: Midtre Lovenbreen, Svaldbard. Polar Biology, 26, 530-537.

Díaz, S., Purvis, A., Cornelissen, J.H.C., Mace, G.M., Donoghue, M.J., et al., (2013) Functional traits, the phylogeny of function, and ecosystem service vulnerability. Ecology and Evolution, 3, $2958-2975$.

Dormann, F., McPherson, C. M., Araujo, J. B., Bivand, M., Bolliger, R., et al., (2007) Methods to account for spatial autocorrelation in the analysis of species distributional data: a review.

Ecography, 30, 609-628. 
488

489

490

491

492

493

494

495

496

497

498

499

500

501

502

503

504

505

506

507

508

509

510

511

512

513

Duffey, E. (1998) Aerial dispersal in spiders. P. A. Selden (ed.). Proceedings of the 17th European Colloquium of Arachnology, Edinburgh 1997: 187-191.

Eymann, J., Degreef, J., Häuser, Ch., Monje, J.C., Samyn, Y. \& VandenSpiegel, D. (2010) Manual on field recording techniques and protocols for All Taxa Biodiversity Inventories and Monitoring. Abc Taxa, Vol. 8, part 2.

Entling, W., Schmidt-Entling, M. H., Bacher, S., Brandl, R. \& Nentwig, W. (2010) Body sizeclimate relationships of European spiders. Journal of Biogeography, 37, 477-485.

Erschbamer, B. \& Mayer, R. (2012) Can successional species groups be discriminated based on their life history traits? A study from a glacier foreland in the Central Alps. Plant Ecology \& Diversity, 4, 341-351.

Gobbi, M., De Bernardi, F., Pelfini, M., Rossaro, B. \& Brandmayr P. (2006) Epigean arthropod succession along a 154 year glacier foreland chronosequence in the Forni Valley (Central Italian Alps). Arctic, Antarctic and Alpine Research, 38, 357-362.

Gobbi, M., Rossaro, B., Vater, A., De Bernardi, F., Pelfini, M. \& Brandmayr, P. (2007)

Environmental features influencing Carabid beetle (Coleoptera) assemblages along a recently deglaciated area in the Alpine region. Ecological Entomology, 32, 682-289.

Gobbi, M., Caccianiga, M., Cerabolini, B., Luzzaro, A. \& De Bernardi, F. (2010) Plant adaptive response during primary succession are associated with functional adaptations in ground beetles on deglaciated terrain. Community Ecology, 11, 223-231. 
514 Gobbi, M., Isaia, M. \& De Bernardi, F. (2011) Arthropod colonization of a debris-covered glacier.

515 The Holocene, 21, 343-349.

516

517 Gobbi, M. \& Brambilla, M. (2016) Patterns of spatial autocorrelation in the distribution and

518 diversity of carabid beetles and spiders along Alpine glacier forelands. Italian Journal of Zoology,

$51983,600-605$.

520

521

522

Hagvar, S. (2012) Primary succession in glacier forelands: how small animals conquer new land around melting glaciers. In: Young S.S and Silvern S.E. International perspective on Global

523 Environmental Change. InTech Ed., 151-172.

524

525

HilleRisLambers, J., Adler, P.B., Harpole, W.S., Levine, J.M. \& Mayfield, M.M. (2012) Rethinking 526 community assembly through the lens of coexistence theory. Annual Review of Ecology Evolution 527 and Systematic, 43, 227-248.

528

529

Homburg, K., Homburg, N., Schäfer, F., Schuldt, A. \& Assmann, T. (2014) Carabids.org - a

530 dynamic online database of ground beetle species traits (Coleoptera, Carabidae). Insect

531 Conservation and Diversity, 7, 195-205.

532

533

Hůrka, K. (1996) Carabidae of the Czech and Slovak Republics, Ceskè a Slovenskè republiky. Zlìn:

534 Kabourek.

535

536 Kaufmann, R., (2001) Invertebrate succession on an Alpine glacier foreland. Ecology, 82, 22615372278.

538 
539 Kotze, D.J., Brandmayr, P., Casale, A., Dauffy-Richard, E., Dekoninck, W., et al., (2011) Forty

540 years of carabid beetle researchin Europe-from taxonomy, biology, ecology and population studies

541 to bioindication, habitat assessment and conservation. ZooKeys, 100, 55-148.

542

543 Laliberté, E. \& Legendre, P. (2010) A distance-based framework for measuring functional diversity

544 from multiple traits. Ecology, 91, 299-305.

545

Laliberté, E., Legendre, P. \& Shipley B. (2014). FD: measuring functional diversity from multiple

547

548

549

550

551

552

553

554

555

556

557

558

559

560

561

562

563

564

traits, and other tools for functional ecology. R package version 1.0-12.

Legendre, P. \& Legendre, L. (2012) Numerical Ecology. Elsevier, Amsterdam, 870 pp.

Losapio, G., Jordán, F., Caccianiga, M. \& Gobbi, M. (2015) Structure-dynamic relationship of plant-insect networks along a primary succession gradient on a glacier foreland. Ecological Modelling, 314, 73-79.

Mason, N.W.H., Richardson, S.J., Peltzer, D.A., de Bello, F., Wardle, D.A., Allen, R.B. (2012) Changes in coexistence mechanisms along a long-term soil chronosequence revealed by functional trait diversity. Journal of Ecology, 100, 678-689.

Mason, N.W.H., de Bello, F., Mouillot, D, Pavoine, S \& Dray, S. (2013) A guide for using functional diversity indices to reveal changes in assembly processes along ecological gradients. Journal of Vegetation Science, 24, 794-806.

Meijer, J. (1977) The immigration of spiders (Araneida) into a new polder. Ecological Entomology, 2, 81-90. 
Moretti, M., Dias, A. T. C., de Bello, F., Altermatt, F., Chown, S. L., et al., (2017), Handbook of

567 protocols for standardized measurement of terrestrial invertebrate functional traits. Functional

568 Ecology, 31, 558-567.

569

570 Nentwig, W., Blick, T., Gloor, D., Hänggi, A. \& Kropf, C. (2017). Spiders of Europe.

571 www.araneae.unibe.ch. Version 02.2017.

572

573

574

575

576

577

578

579

580

581

582

583

584

585

586

587

588

Paul, F., Kääb, A. \& Haeberli, W. (2007) Recent glacier changes in the Alps observed by satellite:

Consequences for future monitoring strategies. Global and Planetary Change, 56, 111-122.

Pesarini, C. \& Monzini, V. (2010) Insetti della Fauna Italiana. Coleotteri Carabidi I. Natura, Rivista di Scienze Naturali, 100, 152 pp.

Pesarini, C. \& Monzini, V. (2011) Insetti della Fauna Italiana. Coleotteri Carabidi II. Natura, Rivista di Scienze Naturali, 101, 144 pp.

Pinheiro J., Bates D, DebRoy S, Sarkar D \& R Core Team (2017). nlme: Linear and Nonlinear Mixed Effects Models. R package version 3.1-129, https://CRAN.R-project.org/package=nlme. 
589

590

591

592

593

594

595

596

597

598

599

600

601

602

603

604

605

606

607

608

609

610

611

612

613

614

Pizzolotto, R., Albertini, A., Gobbi, M. \& Brandmayr, P. (2016) Habitat diversity analysis along an altitudinal sequence of alpine habitats: the Carabid beetle assemblages as a study model.

Periodicum Biologorum, 118, 241-254.

Raso, L., Sint, D., Mayer, R., Plangg, S., Recheis, R., Kaufmann, R. \& Traugott, M., (2014)

Intraguild predation in pioneer predator communities of Alpine glacier forelands. Molecular

Ecology, 23, 3744-3754.

Roberts, M. J. (1985) The spiders of Great Britain and Ireland, Volume 1: Atypidae to

Theridiosomatidae. Harley Books, Colchester, England

Schirmel, J., Blindowa, I. \& Buchholzc, S. (2012) Life-history trait and functional diversity patterns of ground beetles and spiders along a coastal heathland successional gradient. Basic and Applied Ecology, 13, 606-614.

Schleuter, D., Daufresne, M., Massol, F. \& Argillier, C. (2010) A User's guide to functional diversity indices. Ecological Monographs, 80, 469-484.

Tampucci, D., Gobbi, M., Cabrini, E., Compostella, C., Marano, G., Pantini, P. \& Caccianiga, M. (2015) Plant and arthropod colonization of a glacier foreland in a peripheral mountain range.

Biodiversity, 16, 213-223.

Tenan, S., Maffioletti, C., Caccianiga, M., Compostella, C., Seppi, R. \& Gobbi, M. (2016)

Hierarchical models for describing space-for-time variations in insect population size and sex-ratio along a primary succession. Ecological Modelling, 329, 18-28. 
615 Vater, A.E. (2012) Insect and Arachnid Colonization on the Storbreen Glacier Foreland, 616 Jotunheimen, Norway: persistence of Taxa Suggests an Alternative Model of Succession. The 617 Holocene, 22, 1123-1133.

618 619

Vater, A.E. \& Matthews, J.A. (2013) Testing the ‘Addition 40 and Persistence Model' of 620 Invertebrate Succession in a Subalpine Glacier-Foreland Chronosequence: Fåbergstølsbreen, 621 Southern Norway. The Holocene, 23, 1151-1162.

622

Vater, A.E. \& Matthews, J.A. (2015) Succession of Pitfall-Trapped Insects and Arachnids on Eight

624

Norwegian Glacier Forelands along an Altitudinal Gradient: patterns and Models. The Holocene,

625 25, 108-129.

626

627

Venables, W.N. \& Ripley, B.D. (2002) Modern applied statistics with S. Springer, New York

628

629

Vigna Taglianti, A. (2013) Fauna Europaea: Carabidae. In Audisio, P. (ed.): Fauna Europaea

630

Version 2.6. Available at: http://www.faunaeu.org (accessed 01.IV.2016).

631

632

Walkley, A. \& Black, I.A. (1934) An examination of the Degtjareff method for determining soil

633 organic matter, and proposed modification of the chromic acid titrationmethod. Soil Science, $\mathbf{3 7}$ $63429-38$.

635

636

Weyman, G.S., Sunderland, K.D. \& Jepson, P.C. (2002) A review of the evolution and mechanisms

637 of ballooning by spiders inhabiting arable farmland. Ecology, Etology and Evolution, 14, 307-326.

638

639 World Spider Catalog (2017). World Spider Catalog. Natural History Museum Bern, online at 640 http://wsc.nmbe.ch, version 18.0, accessed on January 2017 
Table 1 - Carabid and spider species assemblages and life-history traits in each class of deglaciation (Class $0=$ not yet deglaciated - glacier surface,

Class $1=$ areas deglaciated in the period 1994-2003, Class $2=$ areas deglaciated in the period 1925-1994, Class $3=$ areas deglaciated in the period 1850-1925, and Class 4 = Late Glacial Period). Species abundance is indicated as percentage on total captures of each t tanth. Data about carabid and

\begin{tabular}{|c|c|c|c|c|c|c|c|c|c|}
\hline Carabids & $\begin{array}{c}\text { Class } \\
0\end{array}$ & $\begin{array}{c}\text { Class } \\
1\end{array}$ & $\begin{array}{c}\text { Class } \\
2\end{array}$ & $\begin{array}{c}\text { Class } \\
3\end{array}$ & $\begin{array}{c}\text { Class } \\
4\end{array}$ & Dispersal ability & $\begin{array}{c}\text { Larval hunting } \\
\text { strategies }\end{array}$ & Diet & $\begin{array}{l}\text { Mean body } \\
\text { length }(\mathrm{mm})\end{array}$ \\
\hline Amara erratica & & & 0,41 & 0,55 & 0,27 & zoospermophagous & spermophagous & Omnivorous & 7,2 \\
\hline Carabus adamellicola & & & 0,14 & 3,14 & 1,37 & olphactory tactil predator & surface walker & Carnivorous & 19 \\
\hline Carabus depressus & & & 0,27 & 3,69 & 1,50 & olphactory tactil predator & surface walker & Carnivorous & 22,5 \\
\hline Cychrus attenuatus & & & 0,14 & & & olphactory tactil predator & surface walker & Carnivorous & 15 \\
\hline Nebria germari & 3,28 & 6,83 & 13,11 & 0,68 & 0,14 & olphactory tactil predator & surface runner & Carnivorous & 10,25 \\
\hline Nebria jockischii & & 0,41 & 0,27 & & & olphactory tactil predator & surface runner & Carnivorous & 12,2 \\
\hline Notiophilus biguttatus & & & & 0,14 & 0,41 & visual predator & surface runner & Carnivorous & 5 \\
\hline Oreonebria angustata & & 0,14 & 4,10 & 0,14 & & olphactory tactil predator & surface runner & Carnivorous & 8 \\
\hline
\end{tabular}




\begin{tabular}{|c|c|c|c|c|c|c|c|c|c|c|}
\hline Oreonebria castanea & & & 14,48 & 20,49 & 18,58 & low & olphactory tactil predator & surface runner & Carnivorous & 8,8 \\
\hline Platynus teriolensis & & & & 0,27 & 2,19 & low & olphactory tactil predator & surface walker & Carnivorous & 11,25 \\
\hline Princidium bipunctatum & & & 0,14 & 0,14 & & high & olphactory tactil predator & soil pore explorer & Carnivorous & 4 \\
\hline Pterostichus multipunctatus & & & 0,14 & 2,32 & & low & olphactory tactil predator & soil pore explorer & Carnivorous & 14 \\
\hline Trechus tristiculus & & & 0,14 & & & low & olphactory tactil predator & soil pore explorer & Carnivorous & 4 \\
\hline \multirow[b]{2}{*}{ Spiders } & Class & Class & Class & Class & Class & Dispersal strategies & \multirow[b]{2}{*}{ Hunting strategies } & Mean body & & \\
\hline & $\mathbf{0}$ & & & & & & & length (mm) & & \\
\hline Acantholycosa pedestris & & & 1,10 & & ) & ground disperser & ground hunter & 9,25 & & \\
\hline Agyneta rurestris & 7,69 & & & & 2,20 & ballooner & sheet web weaver & 2,18 & & \\
\hline Arctosa alpigena & & & & & 2,20 & ground disperser & ground hunter & 6,80 & & \\
\hline Coelotes pickardi tirolensis & & & 8,79 & 19,78 & 10,99 & ground disperser & sheet web weaver & 8,85 & & \\
\hline Diplocephalus helleri & & 1,10 & 1,10 & 2,20 & & ballooner & other hunter & 2,18 & & \\
\hline Drassodex heeri & & & & 7,69 & & ground disperser & ground hunter & 18,15 & & \\
\hline Erigone dentipalpis & & 1,10 & 1,10 & & & ballooner & other hunter & 2,33 & & \\
\hline Mughiphantes handschini & & & 4,40 & 1,10 & & ballooner & sheet web weaver & 2,75 & & \\
\hline Oreonetides glacialis & & 1,10 & 1,10 & & & ballooner & sheet web weaver & 2,68 & & \\
\hline Pardosa nigra & 2,20 & 1,10 & 7,69 & 4,40 & 4,40 & ground disperser & ground hunter & 7,75 & & \\
\hline Pardosa oreophila & & & 2,20 & & & ground disperser & ground hunter & 5,55 & & \\
\hline Sitticus longipes & & & & 2,20 & & ground disperser & other hunter & 9,15 & & \\
\hline Tenuiphantes monachus & & & 1,10 & & & ballooner & sheet web weaver & 2,60 & & \\
\hline
\end{tabular}




\section{Ecological Entomology}

Page 32 of 45

649 
650 Table 2 - Summary of the effect of time since deglaciation (class) on the response variables

651 (species richness, species traits and functional indices). The cases for which the effect of time since

652 deglaciation was supported (model including the variable most parsimonious than the null model;

653 see text) are reported in bold; for all other variables, the model with time since deglaciation was less

654 supported than the null model. Values are estimated coefficients ( \pm relative standard error) for the

655 effect of time since deglaciation in relation to class of deglaciation 0 (glacier surface); also the

656 significance of effect is tested again class 0 (legend: * $\mathrm{P}<0.05 ; * * \mathrm{P}<0.01 ; * * *<0.001$ ).

\begin{tabular}{|c|c|c|c|c|c|}
\hline CARABIDS & intercept & Class 1 & Class 2 & Class 3 & Class 4 \\
\hline Species richness & $0.41 \pm 0.43$ & $0.92 \pm 0.72$ & $3.92 \pm 0.72 * * *$ & $4.60 \pm 0.72 * * *$ & $4.92 \pm 0.93 * * *$ \\
\hline $\begin{array}{l}\text { Proportion of } \\
\text { surface walkers }\end{array}$ & $0.00 \pm 0.05$ & $0.00 \pm 0.08$ & $0.09 \pm 0.07$ & $0.28 \pm 0.07 * *$ & $0.50 \pm 0.09 * * *$ \\
\hline $\begin{array}{l}\text { Proportion of } \\
\text { surface runners }\end{array}$ & $1.00 \pm 0.09 * * *$ & $0.00 \pm 0.15$ & $-0.25 \pm 0.13$ & $-0.53 \pm 0.13$ & $-0.59 \pm 0.17 * * *$ \\
\hline $\begin{array}{l}\text { Proportion of soil } \\
\text { explorers }\end{array}$ & $0.00 \pm 0.04$ & $0.00 \pm 0.06$ & $0.09 \pm 0.05$ & $0.18 \pm 0.06 * *$ & $0.00 \pm 0.07$ \\
\hline $\begin{array}{l}\text { Proportion of } \\
\text { winged species }\end{array}$ & $0.00 \pm 0.06$ & $0.38 \pm 0.09 * * *$ & $0.20 \pm 0.08 *$ & $0.11 \pm 0.08$ & $0.11 \pm 0.09$ \\
\hline Mean body lenght & $10.25 \pm 0.84$ & $0.49 \pm 1.34$ & $0.43 \pm 1.17$ & $2.07 \pm 1.17$ & $2.06 \pm 1.55$ \\
\hline FRic & $1.00 \pm 0.48$ & $0.78 \pm 0.75$ & $1.48 \pm 0.65^{*}$ & $2.31 \pm 0.67 * *$ & $2.03 \pm 0.87^{*}$ \\
\hline FRve & $0.30 \pm 0.05$ & & & $0.06 \pm 0.06$ & $-0.14 \pm 0.07$ \\
\hline FDis & $0.00 \pm 0.04$ & $0.04 \pm 0.05$ & $0.07 \pm 0.05$ & $0.11 \pm 0.05^{*}$ & $0.10 \pm 0.06$ \\
\hline $\operatorname{RaoQ} \Omega$ & $0.00 \pm 0.02$ & $0.01 \pm 0.02$ & $0.03 \pm 0.02$ & $0.03 \pm 0.02$ & $0.02 \pm 0.03$ \\
\hline SPIDERS & intercept & Class 1 & Class 2 & Class 3 & Class 4 \\
\hline Species richness & $0.73 \pm 0.31 *$ & $-0.06 \pm 0.52$ & $1.94 \pm 0.52 * * *$ & $1.77 \pm 0.53 * *$ & $2.63 \pm 0.70 * * *$ \\
\hline
\end{tabular}




\begin{tabular}{|c|c|c|c|c|c|}
\hline $\begin{array}{l}\text { Proportion of } \\
\text { ground hunters }\end{array}$ & $0.17 \pm 0.13$ & $0.08 \pm 0.21$ & $0.32 \pm 0.19$ & $0.20 \pm 0.22$ & $0.33 \pm 0.26$ \\
\hline $\begin{array}{l}\text { Proportion of } \\
\text { sheet web } \\
\text { weavers }\end{array}$ & $0.83 \pm 0.12$ & $-0.58 \pm 0.20 * *$ & $-0.38 \pm 0.18 *$ & $-0.42 \pm 0.20 *$ & $-0.33 \pm 0.24$ \\
\hline $\begin{array}{l}\text { Proportion of } \\
\text { ballooners }\end{array}$ & $0.83 \pm 0.13 * * *$ & $-0.07 \pm 0.20$ & $-0.47 \pm 0.18 *$ & $-0.66 \pm 0.20 * * *$ & $-0.63 \pm 0.25 *$ \\
\hline $\begin{array}{l}\text { Mean body } \\
\text { length }\end{array}$ & $3.11 \pm 0.84 * * *$ & $0.61 \pm 1.33$ & $2.86 \pm 1.20 *$ & $5.70 \pm 1.35 * * *$ & $3.80 \pm 1.62 *$ \\
\hline Fric & $1.33 \pm 0.28 * * *$ & $0.66 \pm 0.44$ & $1.50 \pm 0.39 * *$ & $1.67 \pm 0.41 * * *$ & $3.00 \pm 0.48 * * *$ \\
\hline FRve & $0.66 \pm 0.07$ & & & $-0.14 \pm 0.10$ & $-0.02 \pm 0.11$ \\
\hline FDis & $0.16 \pm 0.06$ & $0.16 \pm 0.10$ & $0.23 \pm 0.09 *$ & $0.32 \pm 0.09 *$ & $0.31 \pm 0.11^{*}$ \\
\hline RaoQ & $0.08 \pm 0.04$ & $0.03 \pm 0.06$ & $0.09 \pm 0.05$ & $0.17 \pm 0.05 * *$ & $0.15 \pm 0.06^{*}$ \\
\hline
\end{tabular}

657

658

659 
660

661

662

663

664

665

666

667

668

669

670

671

672

673

674

675

676

677

678

679

680

681

682

683

684

\section{Figures}

Figure 1 - Geographic location of the sampling plots in relation to the chronosequence of glacier retreat. Plots 1, 2, 3, 4= Class 0 (not yet deglaciated - glacier surface); plots 5, 6, = Class 1 (areas freed by the glacier in the period 1994-2003); plots 7, $8=$ Class $2(1925-1994)$; plots 9, $10=$ Class 3 (1850-1925); and plot $11=$ Class 4 (Late Glacial Period).

Figure 2 - Observed (grey dots) and expected (black dots) carabid and spider species richness in relation to the class of deglaciation. Triangles represent $95 \%$ C.I.

Figure 3 - Observed (grey dots) and expected (black dots) spider life-history traits in relation to the class of deglaciation. Only the cases in which the effect of time since deglaciation was supported (model including the variable most parsimonious than the null model; see text) are displayed.

Triangles represent 95\% C.I.

Figure 4 - Observed (grey dots) and expected (black dots) carabid life-history traits in relation to the class of deglaciation. Only the cases in which the effect of time since deglaciation was supported (model including the variable most parsimonious than the null model; see text) are displayed. Triangles represent 95\% C.I.

Figure 5 - Functional trait richness and functional trait first and last appearances among the classes of deglaciation; (A) carabids, (B) spiders.

\section{Supplementary File}

Appendix S1 and S2 
Table 1 - Carabid and spider species assemblages and life-history traits in each class of deglaciation (Class $0=$ not yet deglaciated - glacier surface, Class $1=$ areas deglaciated in the period 1994-2003, Class $2=$ areas deglaciated in the period 1925-1994, Class $3=$ areas deglaciated in the period 1850-1925, and Class 4 = Late Glacial Period). Species abundance is indicated as percentage on total captures of each taxon. Data about carabid and spider life-history traits were obtained on the base of specialized literature (Bell et al., 2005; Blandenier, 2009; Hůrka, 1996; Brandmayr et al., 2005; Homburg et al., 2014; Nentwig et al., 2017.

\begin{tabular}{|c|c|c|c|c|c|c|c|c|c|c|}
\hline Carabids & $\begin{array}{c}\text { Class } \\
0\end{array}$ & $\begin{array}{c}\text { Class } \\
1\end{array}$ & $\begin{array}{c}\text { Class } \\
2\end{array}$ & Class & $\begin{array}{c}\text { Class } \\
4\end{array}$ & Dispersal ability & Adult hunting strategies & $\begin{array}{c}\text { Larval hunting } \\
\text { strategies }\end{array}$ & Diet & $\begin{array}{l}\text { Mean body } \\
\text { length (mm) }\end{array}$ \\
\hline Amara erratica & & & 0,41 & 0,55 & 0,27 & high & zoospermophagous & spermophagous & Omnivorous & 7,2 \\
\hline Carabus adamellicola & & & 0,14 & 3,14 & 1,37 & low & olphactory tactil predator & surface walker & Carnivorous & 19 \\
\hline Carabus depressus & & & 0,27 & 3,69 & 1,50 & low & olphactory tactil predator & surface walker & Carnivorous & 22,5 \\
\hline Cychrus attenuatus & & & 0,14 & & & low & olphactory tactil predator & surface walker & Carnivorous & 15 \\
\hline Nebria germari & 3,28 & 6,83 & 13,11 & 0,68 & 0,14 & low & olphactory tactil predator & surface runner & Carnivorous & 10,25 \\
\hline Nebria jockischii & & 0,41 & 0,27 & & & high & olphactory tactil predator & surface runner & Carnivorous & 12,2 \\
\hline Notiophilus biguttatus & & & & 0,14 & 0,41 & low & visual predator & surface runner & Carnivorous & 5 \\
\hline Oreonebria angustata & & 0,14 & 4,10 & 0,14 & & low & olphactory tactil predator & surface runner & Carnivorous & 8 \\
\hline Oreonebria castanea & & & 14,48 & 20,49 & 18,58 & low & olphactory tactil predator & surface runner & Carnivorous & 8,8 \\
\hline Platynus teriolensis & & & & 0,27 & 2,19 & low & olphactory tactil predator & surface walker & Carnivorous & 11,25 \\
\hline Princidium bipunctatum & & & 0,14 & 0,14 & & high & olphactory tactil predator & soil pore explorer & Carnivorous & 4 \\
\hline
\end{tabular}




\begin{tabular}{|c|c|c|c|c|c|c|c|c|c|c|}
\hline Pterostichus multipunctatus & & & 0,14 & 2,32 & & low & olphactory tactil predator & soil pore explorer & Carnivorous & 14 \\
\hline Trechus tristiculus & & & 0,14 & & & low & olphactory tactil predator & soil pore explorer & Carnivorous & 4 \\
\hline \multirow[b]{2}{*}{ Spiders } & Class & Class & Class & Class & Class & Dispersal strategies & \multirow{2}{*}{ Hunting strategies } & Mean body & & \\
\hline & $\mathbf{0}$ & 1 & 2 & & & of the adult & & length (mm) & & \\
\hline Acantholycosa pedestris & & & 1,10 & & & ground disperser & ground hunter & 9,25 & & \\
\hline Agyneta rurestris & 7,69 & $\bar{c}$ & $\sqrt{3}$ & & 2,20 & ballooner & sheet web weaver & 2,18 & & \\
\hline Arctosa alpigena & & & $x^{2}$ & 2 & 2,20 & ground disperser & ground hunter & 6,80 & & \\
\hline Coelotes pickardi tirolensis & & & 8,79 & 19,78 & 10,99 & ground disperser & sheet web weaver & 8,85 & & \\
\hline Diplocephalus helleri & & 1,10 & 1,10 & 2,20 & 4 & ballooner & other hunter & 2,18 & & \\
\hline Drassodex heeri & & & & 7,69 & & ground disperser & ground hunter & 18,15 & & \\
\hline Erigone dentipalpis & & 1,10 & 1,10 & & & ballooner & other hunter & 2,33 & & \\
\hline Mughiphantes handschini & & & 4,40 & 1,10 & & ballooner & sheet web weaver & 2,75 & & \\
\hline Oreonetides glacialis & & 1,10 & 1,10 & & & ballooner & sheet web weaver & 2,68 & & \\
\hline Pardosa nigra & 2,20 & 1,10 & 7,69 & 4,40 & 4,40 & ground disperser & ground hunter & 7,75 & & \\
\hline Pardosa oreophila & & & 2,20 & & & ground disperser & ground hunter & 5,55 & & \\
\hline Sitticus longipes & & & & 2,20 & & ground disperser & other hunter & 9,15 & & \\
\hline Tenuiphantes monachus & & & 1,10 & & & ballooner & sheet web weaver & 2,60 & & \\
\hline
\end{tabular}


Table 2 - Summary of the effect of time since deglaciation (class) on the response variables (species richness, species traits and functional indices). The cases for which the effect of time since deglaciation was supported (model including the variable most parsimonious than the null model; see text) are reported in bold; for all other variables, the model with time since deglaciation was less supported than the null model. Values are estimated coefficients ( \pm relative standard error) for the effect of time since deglaciation in relation to class of deglaciation 0 (glacier surface); also the significance of effect is tested again class 0 (legend: * $\mathrm{P}<0.05 ; * * \mathrm{P}<0.01 ; * * *<0.001$ ).

\begin{tabular}{|c|c|c|c|c|c|}
\hline CARABIDS & intercept & Class 1 & Class 2 & Class 3 & Class 4 \\
\hline Species richness & $0.41 \pm 0.43$ & $0.92 \pm 0.72$ & $3.92 \pm 0.72 * * *$ & $4.60 \pm 0.72 * * *$ & $4.92 \pm 0.93 * * *$ \\
\hline $\begin{array}{l}\text { Proportion of } \\
\text { surface walkers }\end{array}$ & $0.00 \pm 0.05$ & $0.00 \pm 0.08$ & $0.09 \pm 0.07$ & $0.28 \pm 0.07 * *$ & $0.50 \pm 0.09 * * *$ \\
\hline $\begin{array}{l}\text { Proportion of } \\
\text { surface runners }\end{array}$ & $1.00 \pm 0.09 * * *$ & $0.00 \pm 0.15$ & $-0.25 \pm 0.13$ & $-0.53 \pm 0.13$ & $-0.59 \pm 0.17 * * *$ \\
\hline $\begin{array}{l}\text { Proportion of soil } \\
\text { explorers }\end{array}$ & $0.00 \pm 0.04$ & $0.00 \pm 0.06$ & $0.09 \pm 0.05$ & $0.18 \pm 0.06^{* *}$ & $0.00 \pm 0.07$ \\
\hline $\begin{array}{l}\text { Proportion of } \\
\text { winged species }\end{array}$ & $0.00 \pm 0.06$ & $0.38 \pm 0.09 * * *$ & $0.20 \pm 0.08 *$ & $0.11 \pm 0.08$ & $0.11 \pm 0.09$ \\
\hline Mean body lenght & $10.25 \pm 0.84$ & $0.49 \pm 1.34$ & $0.43 \pm 1.17$ & $2.07 \pm 1.17$ & $2.06 \pm 1.55$ \\
\hline FRic & $1.00 \pm 0.48$ & $0.78 \pm 0.75$ & $1.48 \pm 0.65^{*}$ & $2.31 \pm 0.67 * *$ & $2.03 \pm 0.87 *$ \\
\hline FRve & $0.30 \pm 0.05$ & & & $0.06 \pm 0.06$ & $-0.14 \pm 0.07$ \\
\hline FDis & $0.00 \pm 0.04$ & $0.04 \pm 0.05$ & $0.07 \pm 0.05$ & $0.11 \pm 0.05^{*}$ & $0.10 \pm 0.06$ \\
\hline RaoQ & $0.00 \pm 0.02$ & $0.01 \pm 0.02$ & $0.03 \pm 0.02$ & $0.03 \pm 0.02$ & $0.02 \pm 0.03$ \\
\hline SPIDERS & intercept & Class 1 & Class 2 & Class 3 & Class 4 \\
\hline Species richness & $0.73 \pm 0.31 *$ & $-0.06 \pm 0.52$ & $1.94 \pm 0.52 * * *$ & $1.77 \pm 0.53 * *$ & $2.63 \pm 0.70 * * *$ \\
\hline
\end{tabular}




\begin{tabular}{|c|c|c|c|c|c|}
\hline $\begin{array}{l}\text { Proportion of } \\
\text { ground hunters }\end{array}$ & $0.17 \pm 0.13$ & $0.08 \pm 0.21$ & $0.32 \pm 0.19$ & $0.20 \pm 0.22$ & $0.33 \pm 0.26$ \\
\hline $\begin{array}{l}\text { Proportion of } \\
\text { sheet web } \\
\text { weavers }\end{array}$ & $0.83 \pm 0.12$ & $-0.58 \pm 0.20 * *$ & $-0.38 \pm 0.18^{*}$ & $-0.42 \pm 0.20 *$ & $-0.33 \pm 0.24$ \\
\hline $\begin{array}{l}\text { Proportion of } \\
\text { ballooners }\end{array}$ & $0.83 \pm 0.13 * * *$ & $-0.07 \pm 0.20$ & $-0.47 \pm 0.18 *$ & $-0.66 \pm 0.20 * * *$ & $-0.63 \pm 0.25 *$ \\
\hline $\begin{array}{l}\text { Mean body } \\
\text { length }\end{array}$ & $3.11 \pm 0.84 * * *$ & $0.61 \pm 1.33$ & $2.86 \pm 1.20 \%$ & $5.70 \pm 1.35 * * *$ & $3.80 \pm 1.62 *$ \\
\hline Fric & $1.33 \pm 0.28 * * *$ & $0.66 \pm 0.44$ & $1.50 \pm 0.39 * *$ & $1.67 \pm 0.41 * * *$ & $3.00 \pm 0.48 * * *$ \\
\hline FRve & $0.66 \pm 0.07$ & & & $-0.14 \pm 0.10$ & $-0.02 \pm 0.11$ \\
\hline FDis & $0.16 \pm 0.06$ & $0.16 \pm 0.10$ & $0.23 \pm 0.09 *$ & $0.32 \pm 0.09 *$ & $0.31 \pm 0.11 *$ \\
\hline RaoQ & $0.08 \pm 0.04$ & $0.03 \pm 0.06$ & $0.09 \pm 0.05$ & $0.17 \pm 0.05 * *$ & $0.15 \pm 0.06^{*}$ \\
\hline
\end{tabular}




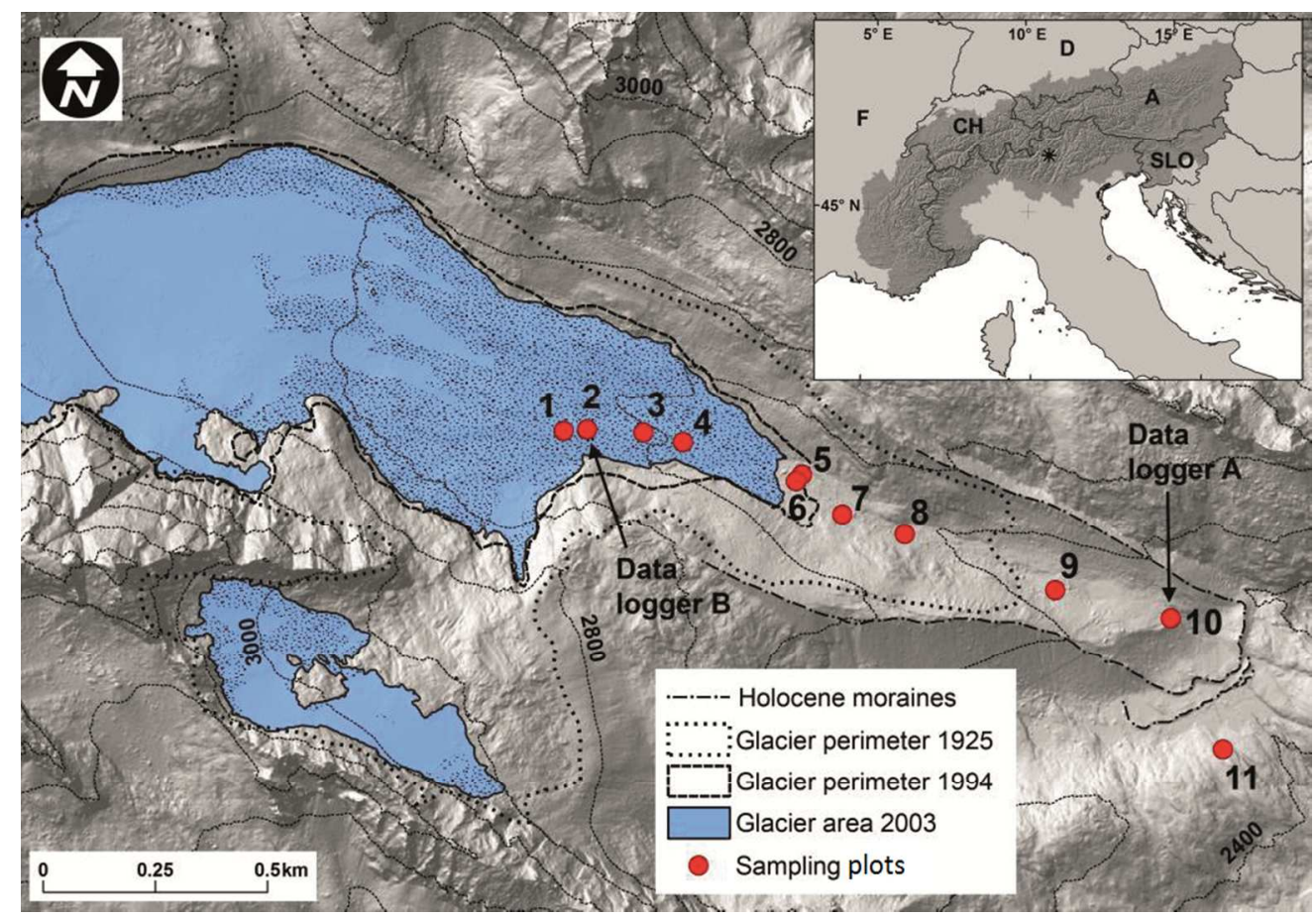

Figure 1 - Geographic location of the sampling plots in relation to the chronosequence of glacier retreat. Plots $1,2,3,4=$ Class 0 (not yet deglaciated - glacier surface); plots 5, 6, = Class 1 (areas freed by the glacier in the period 1994-2003); plots 7, 8 = Class 2 (1925-1994); plots 9, $10=$ Class 3 (1850-1925); and plot $11=$ Class 4 (Late Glacial Period).

$86 \times 60 \mathrm{~mm}(300 \times 300 \mathrm{DPI})$ 

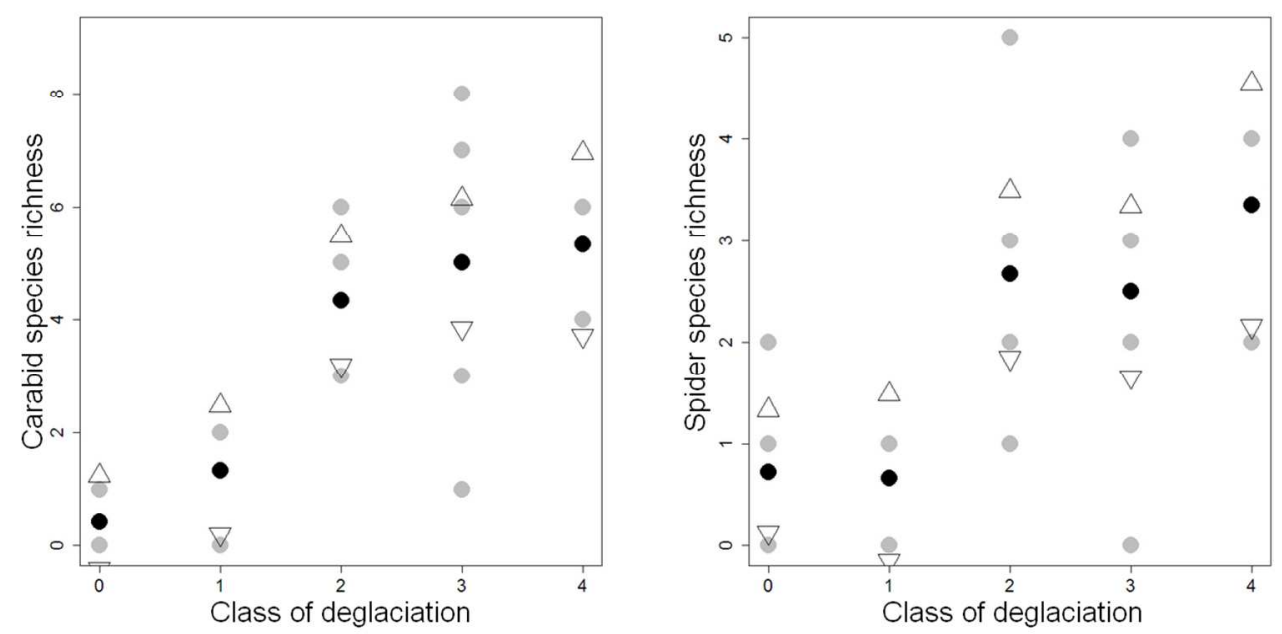

Figure 2 - Observed (grey dots) and expected (black dots) carabid and spider species richness in relation to the class of deglaciation. Triangles represent $95 \%$ C.I.

$106 \times 56 \mathrm{~mm}(300 \times 300 \mathrm{DPI})$ 

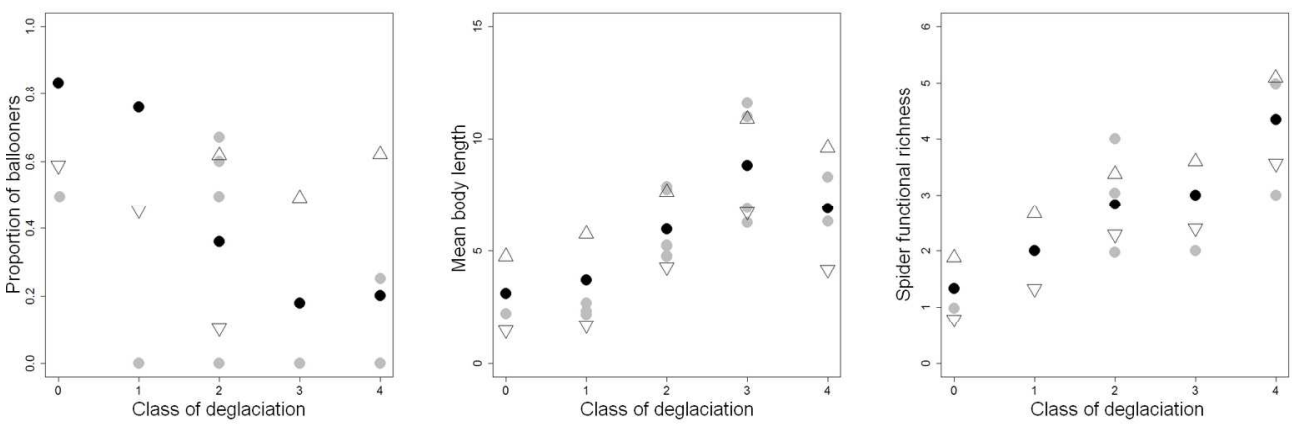

Figure 3 - Observed (grey dots) and expected (black dots) spider life-history traits in relation to the class of deglaciation. Only the cases in which the effect of time since deglaciation was supported (model including the variable most parsimonious than the null model; see text) are displayed. Triangles represent 95\% C.I.

$159 \times 57 \mathrm{~mm}(300 \times 300 \mathrm{DPI})$ 

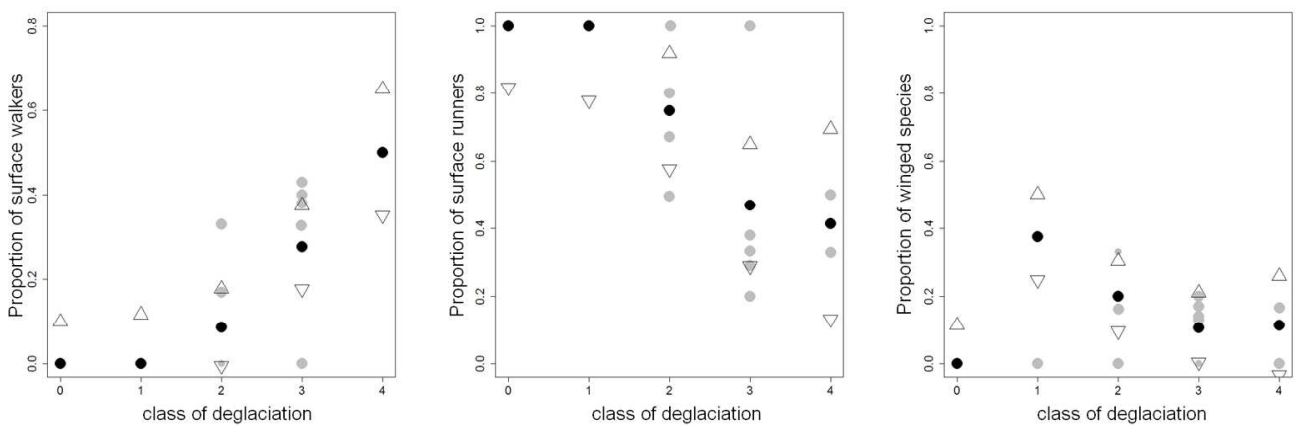

Figure 4 - Observed (grey dots) and expected (black dots) carabid life-history traits in relation to the class of deglaciation. Only the cases in which the effect of time since deglaciation was supported (model including the variable most parsimonious than the null model; see text) are displayed. Triangles represent $95 \%$ C.I. 


\section{A Carabid functional traits}

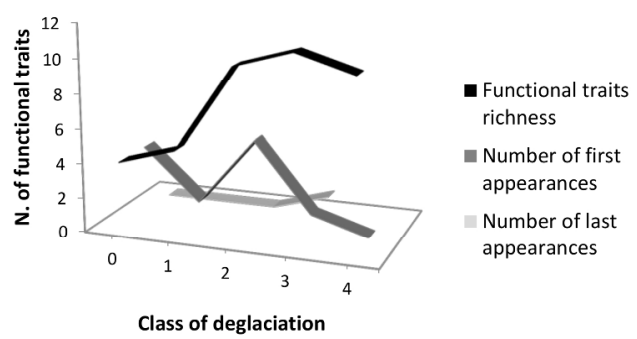

B Spider function traits

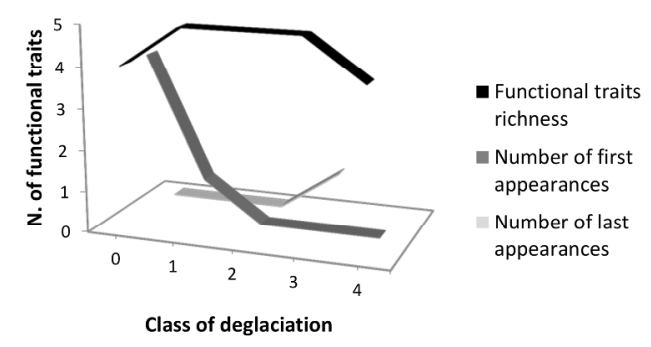

Figure 5 - Functional trait richness and functional trait first and last appearances among the classes of deglaciation; (A) carabids, (B) spiders.

$209 \times 297 \mathrm{~mm}(300 \times 300 \mathrm{DPI})$ 


\section{Acknowledgments}

We thank the Adamello-Brenta Natural Park for issuing the research permit. We are thankful to Silvia Bussolati for her fieldwork assistance. The research project was co-financed by Autonomous Province of Trento (Italy). GL was supported by the Swiss National Science Foundation (PZ00P3_148261). A. E. Vater provided English revision and useful suggestions. The Associate Editor and the three referees provided very helpful comments on a first draft of the manuscript.

\section{Contribution of authors}

Mauro Gobbi designed the experiment, coordinated the research project, wrote the manuscript, participated to the field work, and supervised carabids identification. Francesco Ballarin identified the spiders. Mattia Brambilla performed the statistical analysis in R. Chiara Compostella helped in the fieldwork and performed the soil analysis. Marco Isaia gave a substantial contribution to the writings, especially in the discussion of spiders. Gianalberto Losapio performed the functional diversity analysis adding important insights about the functional diversity trends. Chiara Maffioletti helped on the field work, sorted the arthropods and identified the carabids. Roberto Seppi reconstructed the chronosequence of glacier retreat and gave important information about the glacier features. Duccio Tampucci performed the analysis of species turnover and contributed in writing the paper. Marco Caccianiga helped in the experiment design, participated to the field work, identified the plant species and supervised the final version of the manuscript. 